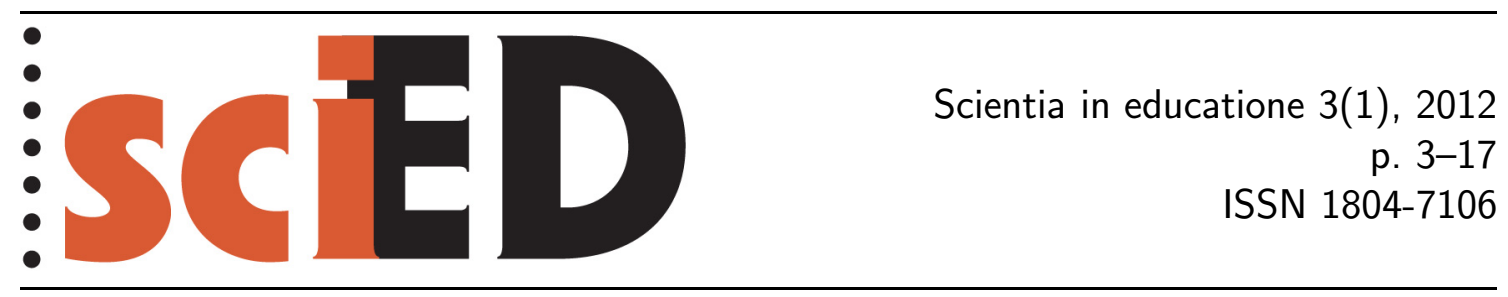

\title{
Výskum používania hier vo vyučovaní fyziky
}

\author{
Jana Horváthová, Viera Haverlíková
}

\begin{abstract}
Abstrakt
V článku sú predstavené výsledky pedagogického výskumu zameraného na zistenie používania hry ako vyučovacej metódy vo fyzike a na identifikovanie faktorov ovplyvňujúcich používanie, resp. nepoužívanie hier učitelmi fyziky nižšieho a vyššieho sekundárneho vzdelávania. V rámci výskumu boli zistované a porovnávané postoje učitelov, ktorí sa vyjadrili, že hru vo vyučovaní používajú a učitelov, ktorí hru neoznačili ako nimi používanú vyučovaciu metódu. Výsledky výskumu poskytujú východiská pre tvorbu didaktických hier, ktoré budú reflektovat potreby, očakávania a obavy učitelov, čo umožní širšie a efektívnejšie používanie hry ako vyučovacej metódy v prírodovednom vzdelávaní.
\end{abstract}

Klíčová slova: hra, vyučovacia metóda, výskum, postoje, fyzika.

\section{Research of Using Games in Physics Education}

\begin{abstract}
The article presents results of research focused on using games as a physics teaching method and identifying factors influencing using or not using games by teachers of lower and upper secondary schools. Attitudes of teachers who claim to be using games in teaching physics are compared to those who do not use them. Results of the research can be used in further development of didactic games that will reflect teachers ${ }^{6}$ needs, expectations and fears in order to enable broader and more effective use of games in science education.
\end{abstract}

Key words: game, teaching methods, research, attitudes, physics. 


\section{1 ÚVOD}

Hra ako činnost’ človeka je stará ako l’udstvo samo. Označuje sa ňou fyzická alebo psychická aktivita, ktorá sa subjektívne vyznačuje kladnými emóciami. Jej znakmi sú dobrovolnost', vyčlenenie v čase a priestore, neistota priebehu a výsledku hry, neproduktívnost', riadenie dohodnutými pravidlami a vedomie inej reality (Caillois, Barash, 2001).

Medzi prvých propagátorov začlenenia hry do vyučovania patril J. A. Komenský, ktorý chápal hru ako prirodzenú potrebu prispievajúcu k rozvoju pohybových funkcií, zmyslov, rozumových schopností, k príprave na prácu. „Hlavnou funkciou hry je podla neho radost a uspokojenie, ktoré dietatu poskytuje, rovnako aj rozvíjajúci vplyv na jeho poznanie." (Klindová v Ďurič a kol., 1997, s. 111) V súčasnosti sa v spojitosti s hrou ako vyučovacou metódou najčastejšie používa pojem didaktická hra.

Didaktická hra ulahčuje, skvalitňuje a zefektívňuje učenie sa žiaka; je dynamizujúcim elementom vzdelávania, efektným a efektívnym prostriedkom transformácie školy z dogmatickej, prinucujúcej učit sa, preferujúcej encyklopedizmus, nezáživnej na školu tvorivú, radostnú, ktorá dokáže plnohodnotne rozvíjat každého žiaka so zretelom na jeho individuálne možnosti a schopnosti. (Petlák, 1997)

Didaktická hra je analógia spontánnej činnosti detí, ktorá sleduje (pre žiakov nie vždy zjavným spôsobom) didaktické ciele. Má svoje pravidlá, vyžaduje priebežné riadenie a záverečné vyhodnotenie. Je určená jednotlivcom aj skupinám žiakov, pričom rola pedagogického vedúceho má široké rozpätie od hlavného organizátora až po pozorovatela. Jej prednostou je stimulačný náboj, lebo prebúdza záujem, zvyšuje angažovanost žiakov na vykonávaných činnostiach, podnecuje ich tvorivost’, spontánnost', spoluprácu aj sútaživost', núti ich využivat rôzne poznatky a schopnosti, zapájat životné skúsenosti. Niektoré didaktické hry sa približujú modelovým situáciám z reálneho života. (Průcha, Walterová, Mareš, 1998)

Medzi hlavné funkcie didaktickej hry sa radia:

- motivácia a aktivizácia;

- fixácia poznatkov, zručností;

- relaxácia;

- socializácia žiakov - žiak vníma svoje prednosti i nedostatky v porovnaní so skupinou, rešpektuje pravidlá hry, vytvára sa sebadisciplinovanost', sebaovládanie, sebakontrola, podporuje sa sebadôvera a samostatnost;

- komunikácia - vyjadrenie určitej myšlienky, výmena vzájomných informácií, aktívne počúvanie tomu, čo hovoria iní;

- rozvoj tvorivosti;

- kognitivizácia - vznik a rozvoj poznatkov a zručností;

- integrácia poznatkov do systému;

- spätná väzba umožňujúca diagnostiku.

Vyučovanie postavené na hre poskytuje skúsenost’ s poznávacím procesom, skúsenosti umožňujúce rôzne spôsoby nazerania na problém, osadenie naučeného do reálneho a relevantného kontextu, podporuje používanie rôznych reprezentácií. Je 
príkladom učenia postaveného na spolupráci, výmene informácií a názorov. Zahŕňa preformulovanie problému, jeho zjednodušenie, zužitkovanie prvotných poznatkov a schopností učiacich sa. Výhodou je tvorba poznatku na základe komplexných kontextových úloh, namiesto izolovaného pozorovania a skúmania. Učenie hrou umožňuje prežívanie údivu a radosti z úspechu, odstraňuje strach z chyby, čím podporuje pozitívny vztah k vzdelávaniu. (Pivec, Dziabenko, Schinnerl, 2004)

Dobrovolné zamestnanie hrou, riešenie problémov obsiahnutých v hre, spontánnost a otvorenost umožňujú pozorovat aktuálnu úroveň vývinu žiaka. Hra oslobodzuje hráča od mnohých sociálnych obmedzení, od nedôvery vo vlastné schopnosti. V hre sa jedinec správa nad svoje priemerné, bežné každodenné správanie. Preukazuje nielen dosiahnuté poznatky, ale hra, ktorá je pre žiaka výzvou, odhaluje aj zónu jeho najbližšieho vývinu.

Z hladiska vlastného poznávania je rozhodujúce prostredie hry, ktoré žiak vníma ako blízke, známe a relevantné. $\mathrm{V}$ takomto prostredí rýchlo vidí a chápe spojenia medzi učebnou skúsenostou a reálnym životom (Trybus, 2009).

Prebiehajúca kurikulárna transformácia zahŕňa nielen zmenu obsahu, ale aj metód vzdelávania. Je zameraná najmä na rozvoj žiackych kompetencií, do popredia stavia aktívnu činnost' žiakov. Východiskom poznávania pritom majú byt aktuálne žiacke predstavy (koncepcie). Rozvoj vzdelávacej hry ako vyučovacej metódy tak reflektuje aktuálne potreby reformujúceho sa školstva.

V našej práci chápeme hru ako fyzickú alebo psychickú činnosṫ jedinca so znakmi dobrovolnosti. Je to aktivita, ktorá prináša pocity radosti, uspokojenia, vedomie inej reality. Hra má svoje jasné pravidlá, priebeh a výsledok; prebieha vo vymedzenom priestore a čase a dá sa realizovat opakovane, môže, ale nemusí mat hrací plán. Didaktická hra má okrem toho vopred presne určený didaktický ciel', ktorý môže byt’ pre žiakov zjavný alebo skrytý. Didaktická hra potom objektívne prispieva k rozvoju osobnosti žiaka, jeho poznatkov a/alebo jeho zručností.

Didaktické hry vo vyučovaní fyziky môžu byt použité vo všetkých vyššie uvedených funkciách, osobitný význam majú pre motiváciu a stimuláciu k d’alšiemu vzdelávaniu s potenciálom odhalit aktuálnu úroveň vývinu žiaka a jeho zónu najbližšieho vývinu.

\section{DIDAKTICKÁ HRA VO VYUČOVANÍ PRÍRODOVEDNÝCH PREDMETOV}

Vo svete v súčasnosti prebieha množstvo výskumov týkajúcich sa dopadu hier na vedomosti a zručnosti žiakov, dominantnou oblastou výskumu je využitie počítačových hier a videohier. Prehlad možno nájst’ v záverečnej správe štúdie Ako sa využívajú digitálne hry v školách (Wastiau, Kearney, Berghe, 2011).

„Výsledky výskumov naznačujú, že počítačová hra samotná alebo prostredie, ktoré vytvára, môžu zlepšit proces učenia. Zavádzanie tejto technológie do tried je však pomalé a hlavnými prekážkami sú nedostatočné vedomosti učitelov o tom, ako využívat' zdroje, nedostatok času na prípravu a prispôsobenie hier ich učebnému plánu, ako aj nedostatok potrebných technológií." (Wastiau, Kearney, Berghe, 2011, s. 142)

Počítačové hry ponúkajú celý rad poznatkov, príležitost' na uplatnenie vlastných vedomostí, podporujú a ulahčujú proces učenia. Žiaci si môžu vyskúšat ako sa výsledok hry mení v závislosti od ich rozhodnutia, rozvíjajú sa komunikačné a sociálne zručnosti v skupine. (Pivec, Dziabenko, Schinnerl, 2004) 
Na Slovensku zatial' nebol realizovaný dostatočný pedagogický výskum dopadu hier, vrátane počítačových, na rozvoj schopností a vedomostí.

Väčšina publikácií týkajúcich sa nepočítačových didaktických hier vo vyučovaní sa týka primárneho vzdelávania (napr. Balážová, 2004, Bóriková, 2007, Kevešová, 2003, Kevešová, 2006, Sabol a kol, 2000-2004), zriedkavo nižšieho sekundárneho vzdelávania - t.j. druhého stupňa základných škôl a nižších ročníkov osemročných gymnázií. Námety na hry a ich zaradenie do vyučovania prírodovedných predmetov môžeme nájsț u viacerých autorov:

- z matematiky napr.: Griščíková, 2007, Kolbaská, 2006, Krupka, 2007, Vankúš, 2003

- zo zemepisu / geografie napr. Dragulová, Vincejová, 2005, Bartošová, 2008;

- z prírodopisu / biológie napr. Hricová, Jakubíková, Tulenková, 2003;

- z fyziky napr. Biznárová, 2003, Haverlíková 2010, Marenčáková, Karászová, 2006.

Problematike počítačových hier sa venuje napr. Bartošová (2008).

Vzdelávacie hry systematicky od r. 1991 rozvíja projekt SCHOLA LUDUS zameraný prednostne na celoživotné neformálne vzdelávanie V rámci SCHOLA LUDUS sú „premyslené i rozvinuté viaceré formy učenia hrou, ktorými žiaci získavajú seriózne skúsenosti, vedomosti, poznatky a zručnosti." (Teplanová, 2007, s. 28) V rámci projektov SCHOLA LUDUS boli vytvorené a v praxi overené fyzikálne vzdelávacie hry Potápač (Biznárová, 2003) a Súboj (Haverlíková, 2010).

S cielom zmapovat používanie hry ako vyučovacej metódy sme v mesiacoch október a november 2010 zrealizovali pedagogický výskum, z ktorého vyplynulo, že učitelia fyziky, ktorí hru do vyučovania zarad’ujú, chápu pod pojmom didaktická hra široké spektrum aktivít. Najčastejšie ide o hry, ktoré sú obdobou televíznych sútaží alebo modifikáciou detských spoločenských hier. Medzi príkladmi hry sa ale vyskytli aj: práca so stavebnicou, zapájanie jednoduchých elektrických obvodov, alebo riešenie úloh. (Horváthová, Haverlíková, 2011, s. 489) Použitie počítačových hier vo vyučovaní fyziky neuviedol ani jeden z respondentov.

\section{PEDAGOGICKÝ VÝSKUM}

\subsection{CiEL A OBSAH PEDAGOGICKÉHO VÝSKUMU}

Hlavným cielom výskumu bolo:

1. zmapovat používanie hry ako vyučovacej metódy učitelmi sekundárneho vzdelávania a zvlášt učitelmi fyziky;

2. identifikovat základné faktory ovplyvňujúce používanie/nepoužívanie metódy hry vo vyučovaní fyziky:

(a) vonkajšie - napríklad vel'kost' školy, vel'kost triedy, zriad'ovatel' školy;

(b) vnútorné - postoje respondentov k vybraným tvrdeniam.

Výskum sa zameral na učitelov, ktorí používajú hry aj tých, ktorí ich vo vyučovaní nepoužívajú. 


\subsection{METÓdA PEDAGOGICKÉHO VÝSKUMU}

V pedagogickom výskume bola využitá metóda elektronického dotazníka. Hra ako vyučovacia metóda nebola v dotazníku definovaná, každý z respondentov hodnotil hru subjektívne cez hry, ktoré vo vyučovaní používa, alebo o ktorých používaní niekedy počul. Metóda elektronického dotazníka bola vybraná pre možnoste časovo a lokálne nezávislého vyplňania respondentmi, zaručenie anonymity pre respondentov a zjednodušenú administráciu s minimálnymi ekonomickými nákladmi.

Vo výskume boli použité:

- otázky s výberom odpovede (jedna odpoved’ je povolená);

- otázky s výberom odpovede (viacero odpovedí je možných);

- otázky s otvorenou odpovedou;

- matice odpovedí (zistovanie postojov na škále: silne nesúhlasím - nesúhlasím súhlasím - silne súhlasím).

\subsection{VÝSKUMNÁ VZORKA}

Výzva na zapojenie sa do výskumu bola elektronickou poštou zaslaná všetkým základným a stredným školám na Slovensku (podla registra Ústavu informácií a prognóz školstva).

Do výskumu sa zapojilo celkom 327 učitelov z minimálne $310^{1}$ základných a stredných škôl, čo predstavuje 10,5 \% škôl v sieti škôl SR (zdroj: ÚIPŠ).

Pri spracovaní výsledkov boli sledované odpovede respondentov v závislosti od vyučovaného predmetu a od stupňa vzdelávania, na ktorom respondenti pôsobia.

V príspevku sú spracované odpovede 167 učitelov fyziky. Z nich 48 sa vyjadrilo, že hru vo vyučovaní fyziky používajú a 119 hru neoznačilo ako používanú vyučovaciu metódu. Celkom 31 učitelov fyziky zapojených do výskumu pôsobilo súbežne na viacerých stupňoch vzdelávania. Početnosti sledovaných skupín respondentov sú uvedené v tabul'ke 1.

Tab. 1: Početnost' sledovaných skupín respondentov

\begin{tabular}{|l|c|c|c|}
\hline & $\begin{array}{c}\text { Zapojení } \\
\text { učitelia } \\
\text { fyziky }\end{array}$ & $\begin{array}{c}\text { Učitelia } \\
\text { fyziky, } \\
\text { ktorí } \\
\text { použivajú } \\
\text { metódu hry }\end{array}$ & $\begin{array}{c}\text { Učitelia } \\
\text { fyziky, } \\
\text { ktorí } \\
\text { nepouživajú } \\
\text { metódu hru }\end{array}$ \\
\hline primárne a nižšie sekundárne vzdelávanie $^{2}$ & 6 & 2 & 4 \\
\hline nižšie sekundárne vzdelávanie $^{2}$ & 101 & 33 & 68 \\
\hline nižšie a vyššie sekundárne vzdelávanie $^{\text {móne }}$ & 25 & 10 & 15 \\
\hline všeobecné vyššie sekundárne vzdelávanie $^{3}$ & 35 & 3 & 32 \\
\hline SPOLU & $\mathbf{1 6 7}$ & $\mathbf{4 8}$ & $\mathbf{1 1 9}$ \\
\hline
\end{tabular}

\footnotetext{
${ }^{1} \mathrm{~V}$ záujme zachovania anonymity respondenti v dotazníku neuvádzali presný názov, resp. adresu školy, preto niektoré školy nebolo možné na základe poskytnutých charakteristík - velkoste školy, zriad’ovatel', územná príslušnost - rozlíšit.

${ }^{2} 5$. až 9. ročník základných škôl a nižšie ročníky osemročných gymnázií.

${ }^{3}$ Štvorročné gymnáziá a prislúchajúce ročníky osemročných gymnázií, odpovede učitelov stredných odborných škôl neboli pre ich velmi nízke zapojenie v prieskume do spracovania výsledkov zaradené.
} 


\subsection{MetóDA ANALÝZY DÁT}

Respondenti hodnotili tvrdenia týkajúce sa hry ako vyučovacej metódy na štvorstupňovej Likertovej škále. Likertova škála bez zaradenia neutrálneho bodu bola zvolená s cielom primät' respondentov zaujat' stanovisko aj v prípade tvrdení, nad ktorými sa doteraz možno nezamýšlali. Postojom boli priradené hodnoty $1=$ silne súhlasím, $2=$ súhlasím, 3 = nesúhlasím, $4=$ silne nesúhlasím. Získané dáta boli spracované štatistickými metódami - určený bol aritmetický priemer a štandardná odchýlka.

Postoje učitelov fyziky, ktorí hru vo vyučovaní používajú a učitelov fyziky, ktorí hru vo vyučovaní nepoužívajú, boli d’alej spracované:

1. štatistickou metódou Test nezávislosti chí-kvadrát pre kontingenčné tabulky, ktorá testuje nulovú hypotézu vyjadrujúcu nezávislost premenných - v našom prípade nezávislost postoja k vybranému tvrdeniu od parametra: používam/nepoužívam hry vo vyučovaní fyziky,

2. znamienkovou schémou pre kontingenčné tabul'ky.

\section{VÝSLEDKY PEDAGOGICKÉHO VÝSKUMU}

Používanie hier vo vyučovaní fyziky bolo vyhodnocované podl’a stupňa vzdelávania, na ktorom respondenti vyučujú. Vnútorné a vonkajšie faktory ovplyvňujúce používanie hier boli vyhodnocované súborne pre učitelov fyziky, ktorí zarad’ujú hry do vyučovania $(n=48)$, a tých ktorí hry do vyučovania nezarad’ujú $(n=119)$.

\subsection{POUŽÍIANIE HIER VO VYUČOVANÍ FYZIKY}

Spomedzi 167 učitel’ov fyziky hru označilo ako používanú metódu celkom 48 učitelov $(28,7 \%$ ). Statisticky významný rozdiel sa preukázal v používaní hry vo vyučovaní fyziky v závislosti od stupňa školského vzdelávania, na ktorom respondent pôsobí (graf 1). Používanie hry vo vyučovaní je na vyššom stupni vzdelávania významne nižšiie.

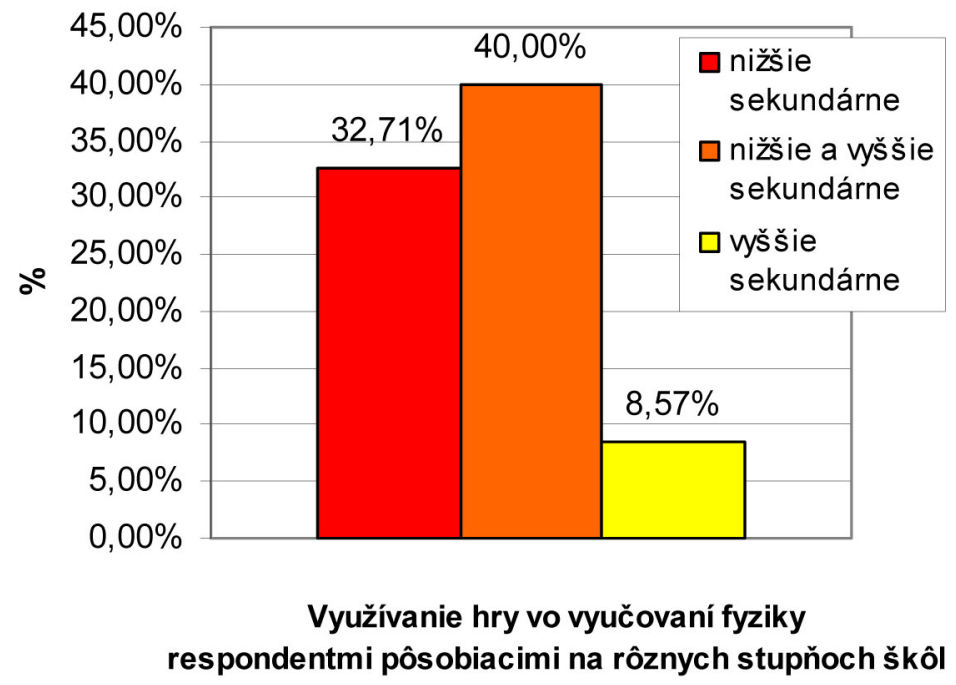

Graf 1: Percentuálne zastúpenie učitelov, ktorí použivajú metódu hry vo vyučovaní fyziky na jednotlivých stupňoch vzdelávania 
Pozn.: Z odpovedí respondentov, ktorí pôsobia súbežne na nižšom a vyššom stupni sekundárneho vzdelávania, nebolo možné určit, či hru používajú na oboch stupňoch vzdelávania, alebo len na jednom z nich. Kedže fyzika sa neučí na primárnom stupni vzdelávania, učitelia, ktorí uviedli, že pôsobia na primárnom aj nižšom sekundárnom stupni, sú v grafe 1. zahrnutí v skupine nižšie sekundárne vzdelávanie.

Tab. 2: Vyhodnotenie zarad’ovania hry do vyučovania v závislosti od vonkajších faktorov

\begin{tabular}{|c|c|c|c|c|c|c|}
\hline \multirow[t]{2}{*}{ FAKTOR } & \multicolumn{2}{|c|}{$\begin{array}{c}\text { Učitelia } \\
\text { fyziky, } \\
\text { ktorí } \\
\text { použivajú } \\
\text { metódu hry }\end{array}$} & \multicolumn{2}{|c|}{$\begin{array}{c}\text { Učitelia } \\
\text { fyziky, } \\
\text { ktorí } \\
\text { nepouživajú } \\
\text { metódu hry } \\
\end{array}$} & \multicolumn{2}{|c|}{$\begin{array}{c}\text { Nulová hypotéza: } \\
\text { Miera použivania } \\
\text { hry nezávisí } \\
\text { od uvedeného } \\
\text { faktora }\end{array}$} \\
\hline & celkom & $\%$ & celkom & $\%$ & $\chi^{2}$ & $\begin{array}{c}\text { Nulovú } \\
\text { hypotézu }\end{array}$ \\
\hline Dížka pedagogickej praxe* & & & & & 3,63 & $\begin{array}{c}\text { nemožno } \\
\text { zamietnut }\end{array}$ \\
\hline do 2 rokov & 6 & 33,3 & 12 & 66,6 & & \\
\hline $3-5$ rokov & 2 & 14,3 & 12 & 85,7 & & \\
\hline $6-10$ rokov & 6 & 23,1 & 20 & 76,9 & & \\
\hline $11-20$ rokov & 17 & 37,0 & 29 & 63,0 & & \\
\hline Viac ako 20 rokov & 17 & 27,0 & 46 & 73,0 & & \\
\hline Velkost’ školy* & & & & & 8,59 & $\begin{array}{c}\text { nemožno } \\
\text { zamietnut }\end{array}$ \\
\hline menej ako 300 žiakov & 23 & 28,0 & 59 & 72,0 & & \\
\hline $301-400$ žiakov & 11 & 52,4 & 10 & 47,6 & & \\
\hline 401-500 žiakov & 3 & 13,0 & 20 & 87,0 & & \\
\hline $501-600$ žiakov & 5 & 26,3 & 14 & 73,7 & & \\
\hline viac ako 600 žiakov & 6 & 27,3 & 16 & 72,7 & & \\
\hline Velkost triedy** & & & & & 0,916 & $\begin{array}{c}\text { nemožno } \\
\text { zamietnut }\end{array}$ \\
\hline do 20 & 11 & 24,4 & 34 & 75,6 & & \\
\hline $20-25$ & 20 & 32,8 & 41 & 67,2 & & \\
\hline nad 25 & 17 & 27,9 & 44 & 72,1 & & \\
\hline Pohlavie respondenta $* * *$ & & & & & 2,56 & $\begin{array}{c}\text { nemožno } \\
\text { zamietnut }\end{array}$ \\
\hline ženy & 41 & 31,8 & 88 & 68,2 & & \\
\hline muži & 7 & 18,4 & 31 & 81,6 & & \\
\hline
\end{tabular}

$\chi^{2}-$ chí kvadrát

Pri spracovaní údajov možných vonkajších faktorov ovplyvňujúcich zaradenie hry do vyučovania, bolo potrebné vzhladom na početnost polí vyhodnocovat údaje pre rôzny stupeň vol’nosti:

*štyri stupne volnosti, $\chi_{k r i t}(0,05)=9,49, \chi_{k r i t}(0,01)=13,28$

$* *$ dva stupne volnosti, $\chi_{k r i t}(0,05)=5,991, \chi_{k r i t}(0,01)=9,210$

$* * *$ jeden stupeň volnosti, $\chi_{k r i t}(0,05)=3,841, \chi_{k r i t}(0,01)=6,635$ 
Vo výskume boli učitelia, ktorí uviedli, že využivajú hru ako vyučovaciu metódu, vyzvaní, aby stručne charakterizovali nimi využívané hry. Z uvedených opisov možno dedukovat, že ide o hry prevažne fixačné $(79,57 \%$ ) a hry podporujúce vznik a rozvoj poznatkov a zručností (22,05 \%) (Horváthová, Haverlíková, 2010, s. 156).

\subsection{VONKAJŠIE OVPLYVŇUJÚCE FAKTORY}

Na základe sledovaných charakteristík (Tab. 2) možno tvrdit, že miera používania hry vo vyučovaní fyziky nie je závislá od dĺžky pedagogickej praxe učitela, od vel'kosti školy, od vel'kosti triedy, v ktorej učitel' učí fyziku, ani od toho, či je učitelom muž alebo žena. Pre malú početnoste zapojených učitelov pôsobiacich na cirkevných školách nebolo možné rozhodnút o závislosti použivania hry od typu zriad’ovatela školy.

\subsection{VNÚTORNÉ OVPLYVŇUJÚCE FAKTORY - POSTOJE UČITEL'OV FYZIKY K POUŽÍIANIU HRY AKO VYUČOVACEJ METÓDY}

Graf 2 znázorňuje zastúpenie postojov sledovaných skupín respondentov k dvanástim tvrdeniam (T1-T12) týkajúcim sa hodnotenia hry ako vyučovacej metódy. V tabul'ke 3 sú uvedené štatistické vyhodnotenia odpovedí respondentov. Kedže test nezávislosti chí-kvadrát nemožno použit v prípadoch, ked’ sú vo viac ako $20 \%$ polí kontingenčnej tabulkky očakávané hodnoty menšie ako 5 a v prípade, že v niektorom poli je očakávaná početnost menšia ako jedna (Chráska, 2010, s. 78), bolo v niektorých prípadoch delenie postojov upravené tak, aby boli uvedené podmienky splnené. Pristúpili sme k zlučovaniu polí - postojov silne nesúhlasím a nesúhlasím, resp. súhlasím a silne súhlasím, čo je podl’a Anděla (1998) prípustné.
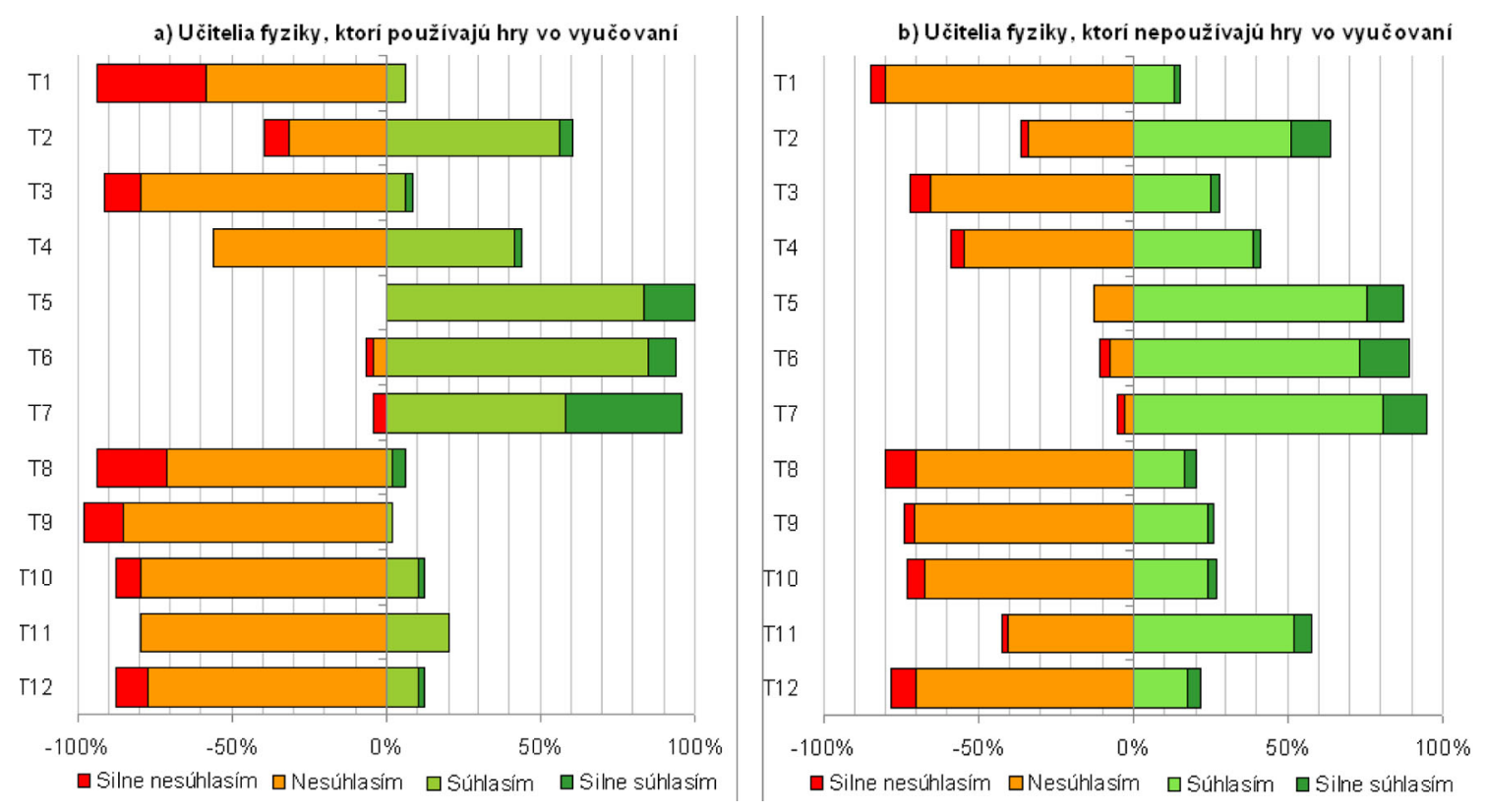

Graf 2: Relatívna početnost' postojov učitelov fyziky: a) ktorí používajú metódu hry vo vyučovaní $(n=48)$, b) ktorí nepoužívajú metódu hry vo vyučovaní $(n=119)$

T1: Použitie hry vo vyučovaní je stratou času

T2: Použit hru vo vyučovaní vyžaduje dlhú prípravu (miestnoste, pomôcky, ...)

T3: Hra je výchovná, nie vzdelávacia metóda

T4: Hrou si žiaci môžu naučené precvičit, nie učit sa niečo nové 
Tab. 3: Vyhodnotenie postojov $\mathrm{k}$ tvrdeniam T1-T12

\begin{tabular}{|c|c|c|c|c|c|c|c|c|}
\hline \multirow{2}{*}{\multicolumn{2}{|c|}{ Tvrdenie }} & \multicolumn{2}{|c|}{$\begin{array}{c}\text { Učitelia } \\
\text { fyziky, } \\
\text { ktorí } \\
\text { použivajú } \\
\text { metódu hry }\end{array}$} & \multicolumn{2}{|c|}{$\begin{array}{c}\text { Učitelia } \\
\text { fyziky, } \\
\text { ktorí } \\
\text { nepouživajú } \\
\text { metódu hry }\end{array}$} & \multirow[t]{2}{*}{$\begin{array}{l}\text { Rozdiel } \\
\\
\bar{x}_{1}-\bar{x}_{2}\end{array}$} & \multicolumn{2}{|c|}{$\begin{array}{l}\text { Nulová hypotéza: } \\
\text { Postoj nezávisí } \\
\text { od toho, či } \\
\text { učitel' hru použiva } \\
\text { (2 stupne volnosti, } \\
\chi_{k r i t}(0,05)=5,991 \\
\left.\chi_{k r i t}(0,01)=9,210\right)\end{array}$} \\
\hline & & $\overline{x_{1}}$ & $\bar{\sigma}$ & $\overline{x_{2}}$ & $\sigma$ & & $\chi^{2}$ & $\begin{array}{c}\text { Nulovú } \\
\text { hypotézu }\end{array}$ \\
\hline $\mathrm{T} 1$ & $\begin{array}{l}\text { Použitie hry vo } \\
\text { vyučovaní je stratou } \\
\text { času }\end{array}$ & 3,29 & 0,58 & 2,88 & 0,49 & 0,41 & 27,20 & $\begin{array}{c}\text { možno } \\
\text { zamietnut }\end{array}$ \\
\hline $\mathrm{T} 2$ & $\begin{array}{l}\text { Použit' hru vo } \\
\text { vyučovaní vyžaduje } \\
\text { dlhú prípravu } \\
\text { (miestnost', } \\
\text { pomôcky, ... ) }\end{array}$ & 2,44 & 0,70 & 2,26 & 0,70 & 0,18 & 2,66 & $\begin{array}{c}\text { nemožno } \\
\text { zamietnut' }\end{array}$ \\
\hline T3 & $\begin{array}{l}\text { Hra je výchovná, nie } \\
\text { vzdelávacia metóda }\end{array}$ & 3,02 & 0,52 & 2,76 & 0,60 & 0,26 & 8,08 & $\begin{array}{c}\text { možno } \\
\text { zamietnut }\end{array}$ \\
\hline $\mathrm{T} 4$ & $\begin{array}{l}\text { Hrou si žiaci môžu } \\
\text { naučené precvičit, nie } \\
\text { učit sa niečo nové }\end{array}$ & 2,54 & 0,54 & 2,61 & 0,61 & $-0,07$ & 2,09 & $\begin{array}{c}\text { nemožno } \\
\text { zamietnut' }\end{array}$ \\
\hline $\mathrm{T} 5$ & $\begin{array}{l}\text { To, čo žiaci zistia pri } \\
\text { hre, si lepšie } \\
\text { zapamätajú }\end{array}$ & 1,83 & 0,37 & 2,01 & 0,49 & $-0,18$ & 6,93 & $\begin{array}{c}\text { možno } \\
\text { zamietnut }\end{array}$ \\
\hline T6 & $\begin{array}{l}\text { Vhodná hra je pre } \\
\text { žiakov motivujúca, } \\
\text { stimuluje ich dalšie } \\
\text { učenie }\end{array}$ & 2,00 & 0,46 & 1,98 & 0,61 & 0,02 & 2,90 & $\begin{array}{c}\text { nemožno } \\
\text { zamietnut' }\end{array}$ \\
\hline $\mathrm{T} 7$ & Hra rozvíja tvorivost & 1,71 & 0,68 & 1,93 & 0,51 & $-0,22$ & 11,15 & $\begin{array}{c}\text { možno } \\
\text { zamietnut }\end{array}$ \\
\hline T8 & $\begin{array}{l}\text { Hra neprispieva } \\
\mathrm{k} \text { vnímaniu } \\
\text { vyučovania ako } \\
\text { zodpovednej } \\
\text { a cielavedomej činnosti }\end{array}$ & 3,13 & 0,63 & 2,87 & 0,62 & 0,26 & 8,19 & $\begin{array}{c}\text { možno } \\
\text { zamietnut }\end{array}$ \\
\hline T9 & $\begin{array}{l}\text { Hra žiakov rozptyluje, } \\
\text { odvádza pozornost od } \\
\text { cielov vzdelávania }\end{array}$ & 3,10 & 0,37 & 2,76 & 0,53 & 0,34 & 16,03 & $\begin{array}{c}\text { možno } \\
\text { zamietnut }\end{array}$ \\
\hline T10 & $\begin{array}{l}\text { Pri hre sa nedá udržat } \\
\text { disciplína a poriadok } \\
\text { v triede }\end{array}$ & 2,94 & 0,52 & 2,76 & 0,59 & 0,18 & 4,11 & $\begin{array}{c}\text { nemožno } \\
\text { zamietnut }\end{array}$ \\
\hline T11 & $\begin{array}{l}\text { Pri hre majú žiaci } \\
\text { pocit, že ide } \\
\text { o neviazanú zábavu }\end{array}$ & 2,79 & 0,41 & 2,38 & 0,62 & 0,41 & $18,94^{*}$ & $\begin{array}{c}\text { možno } \\
\text { zamietnut } *\end{array}$ \\
\hline T12 & $\begin{array}{l}\text { Ak sa učitel’ so žiakmi } \\
\text { často hrá, prestávajú } \\
\text { ho žiaci bratt vážne }\end{array}$ & 2,96 & 0,54 & 2,82 & 0,63 & 0,14 & 1,97 & $\begin{array}{c}\text { nemožno } \\
\text { zamietnut' }\end{array}$ \\
\hline
\end{tabular}

$\bar{x}_{1}, \bar{x}_{2}$ - aritmetický priemer, $\sigma$ - štandardná odchýlka, $\chi^{2}$ - chí kvadrát

*Pri spracovaní postojov k tvrdeniu T11 boli oba krajné postoje málopočetné, pre účely testu nezávislosti chí-kvadrát boli zlúčené postoje sile nesúhlasím a nesúhlasím aj postoje súhlasím a silne súhlasím (jeden stupeň volnosti, $\left.\chi_{k r i t}(0,05)=3,841 ; \chi_{k r i t}(0,01)=6,635\right)$. 
T5: To, čo žiaci zistia pri hre, si lepšie zapamätajú

T6: Vhodná hra je pre žiakov motivujúca, stimuluje ich d’alšie učenie

T7: Hra rozvíja tvorivost

T8: Hra neprispieva k vnímaniu vyučovania ako zodpovednej a cielavedomej činnosti

T9: Hra žiakov rozptyluje, odvádza pozornost’ od cielov vzdelávania

T10: Pri hre sa nedá udržat disciplína a poriadok v triede

T11: Pri hre majú žiaci pocit, že ide o neviazanú zábavu

T12: Ak sa učitel' so žiakmi často hrá, prestávajú ho žiaci brat̉ vážne

Pri tvrdeniach T2, T5, T6 a T7 sme zistili pozitívny trend $(\bar{x}<2,5)$. Pri tvrdeniach T1, T3, T4, T8, T9, T10, T11 a T12 sme zistili negatívny trend $(\bar{x}>2,5)$.

T1: Učitelia fyziky $v$ priemere nepovažujú použitie hry vo vyučovaní za stratu času. Medzi postojmi sledovaných skupín respondentov je štatisticky významný rozdiel na hladine významnosti 0,001 . V skupine učitelov, ktorí hru vo vyučovaní používajú, je pozorovaná početnost silne nesúhlasiacich významne vyššia, než očakávaná na hladine 0,001 . Naopak v skupine učitel'ov, ktorí hru vo vyučovaní nepoužívajú, je pozorovaná početnost' silne nesúhlasím významne nižšia, než očakávaná na hladine 0,01 .

T2: Učitelia fyziky $v$ priemere súhlasia $\mathrm{s}$ tvrdením, že použitie hry vo vyučovaní vyžaduje dlhú prípravu prostredia a pomôcok. Medzi postojmi učitel'ov, ktorí hru vo vyučovaní používajú a tých, ktorí hru nepoužívajú, nebol štatisticky významný rozdiel.

T3: Učitelia fyziky $v$ priemere nesúhlasia s tvrdením, že hra je výchovnou, ale nie vzdelávacou metódou. Medzi postojmi sledovaných skupín respondentov je štatisticky významný rozdiel na hladine významnosti 0,05 . V skupine učitelov, ktorí hru vo vyučovaní používajú, je pozorovaná početnost súhlasiacich a silne súhlasiacich významne nižšia, než očakávaná.

T4: Učitelia fyziky v priemere nesúhlasia s tvrdením, že hrou si žiaci môžu naučené precvičit ale nie naučit sa niečo nové. S uvedeným tvrdením však súhlasí alebo silne súhlasí až 43,7 \% učitelov, ktorí hru vo vyučovaní fyziky používajú. Medzi postojmi učitelov, ktorí hru vo vyučovaní použivajú a tých, ktorí hru nepoužívajú, nebol štatisticky významný rozdiel.

T5: Učitelia fyziky v priemere súhlasia s tvrdením, že to, čo žiaci zistia pri hre, si lepšie zapamätajú. Medzi postojmi sledovaných skupín respondentov je štatisticky významný rozdiel na hladine významnosti 0,05 . V skupine učitelov, ktorí hru vo vyučovaní používajú, je pozorovaná početnost' učitelov, ktorí s tvrdením silne nesúhlasia významne nižšia, než očakávaná.

T6: Učitelia fyziky v priemere súhlasia s tvrdením, že vhodná hra je pre žiakov motivujúca a stimuluje ich $\mathbf{k}$ dalšiemu učeniu. Medzi postojmi učitel'ov, ktorí hru vo vyučovaní používajú a tých, ktorí hru nepoužívajú, nebol štatisticky významný rozdiel.

T7: Učitelia fyziky v priemere súhlasia s tvrdením, že hra rozvíja tvorivost. Medzi postojmi sledovaných skupín respondentov je štatisticky významný rozdiel na hladine významnosti 0,01 . V skupine učitelov, ktorí hru vo vyučovaní používajú, je pozorovaná početnost silne nesúhlasiacich významne nižšia, než očakávaná na hladine 0,05 a pozorovaná početnost’ súhlasiacich a silne súhlasiacich významne vyššia, než očakávaná na hladine 0,01 .

T8: Učitelia fyziky $v$ priemere nesúhlasia $s$ tvrdením, že hra neprispieva k vnímaniu vyučovania ako zodpovednej a cielavedomej činnosti. Medzi postojmi sledovaných skupín respondentov je štatisticky významný rozdiel na hladine významnosti 0,05 . 
T9: Učitelia fyziky $v$ priemere nesúhlasia s tvrdením, že hra žiakov rozptyluje a odvádza ich pozornost' od ciel’ov vzdelávania. Medzi postojmi sledovaných skupín respondentov je štatisticky významný rozdiel na hladine významnosti 0,01 . V skupine učitelov, ktorí hru vo vyučovaní používajú, je pozorovaná početnost’ učitelov, ktorí s tvrdením súhlasia a silne súhlasia významne nižšia, než očakávaná.

T10: Učitelia fyziky $\mathrm{v}$ priemere nesúhlasia $\mathrm{s}$ tvrdením, že pri hre sa nedá udržat disciplína a poriadok v triede. Medzi postojmi učitelov, ktorí hru vo vyučovaní používajú a tých, ktorí hru nepouživajú, nebol štatisticky významný rozdiel.

T11: Učitelia fyziky, ktorí hru vo vyučovaní použivajú, v priemere nesúhlasia s tvrdením, že pri hre majú žiaci pocit, že ide o neviazanú zábavu. Učitelia, ktorí hru vo vyučovaní nepouživajú, s týmto tvrdením v priemere súhlasia. Rozdiel je štatisticky významný na hladine 0,001 . V odpovediach učitelov, ktorí používajú hry vo vyučovaní fyziky, sa vôbec nevyskytli krajné postoje „silne súhlasím“, resp. „silne nesúhlasím“.

T12: Učitelia fyziky v priemere nesúhlasia s tvrdením, že ak sa učitel' so žiakmi často hrá, prestávajú ho žiaci brat vážne. Medzi postojmi učitelov, ktorí hru vo vyučovaní používajú a tých, ktorí hru nepoužívajú, nebol štatisticky významný rozdiel.

So zámerom zistit, či učitelia fyziky používajú hry plánovane integrované do vyučovacieho procesu, alebo len na vyplnenie zostávajúceho času, bolo učitelom, ktorí označili hru ako jednu z použivaných vyučovacích metód predložené d’alšie tvrdenie.

T13: „Hru počas hodiny využívam len ak mi ostane čas“.

Odpovede respondentov sú znázornené v grafe 3 a štatisticky spracované v tabul'ke 4.

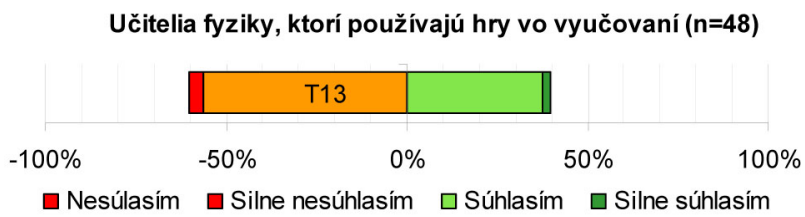

Graf 3: Postoje učitelov fyziky, ktorí používajú metódu hry vo vyučovaní

Tab. 4: Vyhodnotenie postojov $\mathrm{k}$ tvrdeniu T13

\begin{tabular}{|l|l|c|c|}
\hline \multicolumn{2}{|l|}{ Tvrdenie } & \multicolumn{2}{|c|}{$\begin{array}{c}\text { Učitelia fyziky, } \\
\text { ktorí použivajú } \\
\text { metódu hry }\end{array}$} \\
\cline { 3 - 4 } \multicolumn{2}{|l|}{} & $\bar{x}$ & $\sigma$ \\
\hline T13 & Hru počas hodiny využívam len vtedy, ak mi ostane čas & 2,63 & 0,60 \\
\hline
\end{tabular}

T13: Učitelia fyziky, ktorí použivajú hry vo vyučovaní, v priemere nesúhlasia s tvrdením, že hru využivajú počas hodiny len vtedy, ked' im ostane čas. S uvedeným tvrdením však súhlasí alebo silne súhlasí takmer $40 \%$ respondentov.

Ďalšie príčiny nezarad’ovania hry do vyučovania fyziky boli zistované prostredníctvom tvrdení:

T14: Moji žiaci/študenti už sú na hru vel'kí/starí, hra ich už nezaujíma 
T15: Hru by som zaradil do vyučovacieho procesu v prípade vyššej hodinovej dotácie

T16: Nepoznám hry, ktoré by boli určené na vyučovanie fyziky

Postoje učitelov, ktorí hru vo vyučovaní fyziky nepouživajú sú znázornené v grafe 4 a štatisticky vyhodnotené v tabul'ke 5 .

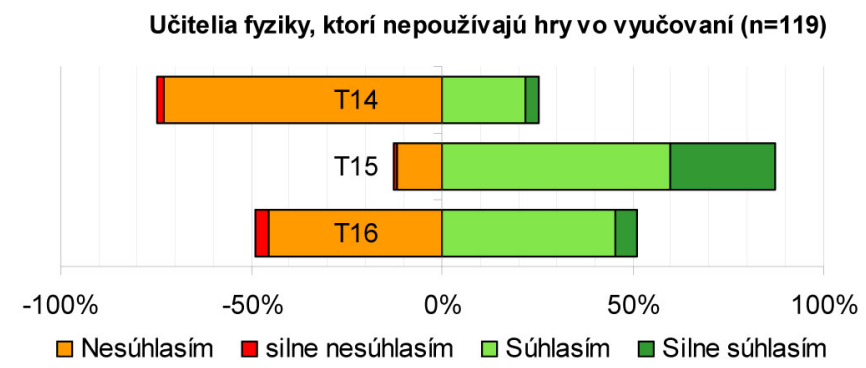

Graf 4: Postoje učitelov fyziky, ktorí nepouživajú metódu hry vo vyučovaní

Tab. 5: Vyhodnotenie postojov $\mathrm{k}$ tvrdeniam T14-T16

\begin{tabular}{|c|c|c|c|}
\hline \multirow{2}{*}{\multicolumn{2}{|c|}{ Tvrdenie }} & \multicolumn{2}{|c|}{$\begin{array}{l}\text { Učitelia fyziky, } \\
\text { ktorí použivajú } \\
\text { metódu hry }\end{array}$} \\
\hline & & $\bar{x}$ & $\sigma$ \\
\hline T14 & $\begin{array}{l}\text { Moji žiaci/študenti už sú na hru velkí/starí, hra ich už } \\
\text { nezaujíma }\end{array}$ & 2,73 & 0,55 \\
\hline $\mathrm{T} 15$ & $\begin{array}{l}\text { Hru by som zaradil do vyučovacieho procesu v prípade } \\
\text { vyššej hodinovej dotácie }\end{array}$ & 1,86 & 0,64 \\
\hline T16 & Nepoznám hry, ktoré by boli určené na vyučovanie fyziky & 2,46 & 0,66 \\
\hline
\end{tabular}

T14: Učitelia fyziky, ktorí nepouživajú hry vo vyučovaní, v priemere nesúhlasia s tvrdením, že ich žiaci, resp. študenti sú na hru starí a hra ich už nezaujíma. Postoj nesúhlasím alebo silne nesúhlasím označilo celkom 74,79 \% respondentov. U učitel'ov fyziky, ktorí nezaradujú hru do vyučovania fyziky bol pozorovaný nárast zastúpenia postojov „súhlasím“ a „silne súhlasím“ s tvrdením so zvyšujúcim sa stupňom vzdelávania - 20,6 \% učitel’ov nižšieho sekundárneho vzdelávania a 40,6 \% učitelov vyššieho sekundárneho vzdelávania Rozdiel je štatisticky významný na hladine 0,05 .

T15: Učitelia fyziky, ktorí nepouživajú hry vo vyučovaní, v priemere súhlasia s tvrdením, že hru by v prípade vyššej hodinovej dotácie zaradili do vyučovacieho procesu. S uvedeným tvrdením súhlasilo alebo silne súhlasilo až $84,87 \%$.

T16: Učitelia fyziky, ktorí nepouživajú hry vo vyučovaní, v priemere súhlasia s tvrdením, že nepoznajú hry, ktoré by boli určené na vyučovanie fyziky. S uvedeným tvrdením súhlasilo alebo silne súhlasilo $51 \%$ učitelov.

\section{ZÁVER}

Na základe odpovedí 167 učitel’ov fyziky zapojených do pedagogického výskumu sme zistili, že hru zarad’uje do vyučovania celkovo len 28,7 \% respondentov. Miera používania hry s rastúcim stupňom vzdelávania klesá. Na základe príkladov hier, ktoré 
učitelia v dotazníku uvádzali, možno dedukovat, že vo vyučovaní fyziky využívajú hru prevažne ako metódu motivačnú a fixačnú.

Používanie hry nezávisí od vel'kosti školy, velkosti triedy, v ktorej učitel' učí fyziku, ani od dížky pedagogickej praxe, či pohlavia učitela.

Učitelia fyziky bez rozdielu - tí, čo hru do vyučovania zarad'ujú aj tí, ktorí hru do vyučovania nezarad’ujú - vnímajú hru ako vzdelávaciu vyučovaciu metódu, ktorá pomáha žiakom rozvíjat' tvorivost', podporuje lepšie zapamätanie si zisteného/naučeného, motivuje a stimuluje k d’alšiemu učeniu.

Učitelia fyziky, ktorí hru na hodinách používajú, nesúhlasia s tvrdeniami, že:

- hra je stratou času, aj ked' jej prípravu na zaradenie do vyučovania považujú za časovo náročnú;

- hra je metóda, ktorá neprispieva k zodpovednej a cielavedomej činnosti;

- pri hre majú žiaci pocit, že ide o neviazanú zábavu.

Aj napriek uvedenému až $40 \%$ z učitelov fyziky, ktorí hru používajú, zarad’uje hru do vyučovania, iba ak im zostane čas. Učitelia zrejme nepovažujú hru za dostatočne efektívnu vyučovaciu metódu.

Učitelia fyziky, ktorí hru na hodinách nepoužívajú, v priemere súhlasia s tvrdeniami, že:

- hru by zaradili do vyučovacieho procesu v prípade vyššej hodinovej dotácie;

- nepoznajú hry, ktoré by boli určené na vyučovanie fyziky;

- pri hre majú žiaci pocit, že ide o neviazanú zábavu.

Na základe realizovaného výskumu možno dedukovat, že hlavnými príčinami nezarad'ovania hry do vyučovania fyziky sú:

- nízku časová dotácia vyučovania fyziky;

- nedostatok hier určených na vyučovanie fyziky;

- obava učitelov, že žiaci by hru vnímali ako neviazanú zábavu.

Nízku mieru používania hry vo vyučovaní fyziky ovplyvňuje aj časová náročnost prípravy hry a presvedčenie takmer $42 \%$ respondentov, že hra je vhodná na precvičovanie, nie na osvojovanie nových poznatkov a zručností.

Väčšina učitelov fyziky je však zároveň presvedčená, že to, čo žiaci zistia pri hre, si lepšie zapamätajú a že vhodná hra stimuluje žiakov k d’alšiemu učeniu.

V záujme využit potenciál hry ako vyučovacej metódy a zvýšit mieru jej používania vo vyučovaní fyziky je preto potrebné v prvom rade vytvorit dostatok vzdelávacích hier, v praxi overit ich dopad na vedomosti a zručnosti žiakov a metodicky ich spracovat pre priame použitie $\mathrm{v}$ školskej praxi.

\section{LITERATURA}

ANDĚL, J. Statistické metody. Praha : MATFYZ. press, MFF-UK, 1998.

BALÁŽOVÁ, E. a kol. Hračky v škole. Banská Bystrica: Vedecká hračka, občianske združenie, 2004. 
BARTOŠOVÁ, L. Vzdelávacie počítačové hry. In 6. ročník konference ALTERNATIVÍ METODY VÝUKY 2008, Praha, 22. 4. 2000. Zborník [on-line]. 2008 [cit. 12. 12. 2010]. Dostupné z:

〈http://everest.natur.cuni.cz/konference/2008/prispevek/bartosova.pdf $\rangle$

BIZNÁROVÁ, V. Fyzikálna hra pre základné školy „Potápač“, In. Sbornik z konference Veletrh nápadi̊ učitelů fyziky 8. České Budějovice : Jihočeská Universita, 2003, s. 71-75. ISBN 80-7040-647-X.

BÓRIKOVÁ, J. Didaktické hry z matematiky pre I. stupeň základných škôl. 2007. [cit. 22. 3. 2011]. Dostupné z:

〈http://www.zborovna.sk/kniznica.php?action=show_version\&id=1195〉

CAILLOIS, R., BARASH, M. Man, play and games. University of Illinois Press, 2001, s. $9-10$.

DRAGULOVÁ, A., VINCEJOVÁ, E. Didaktické hry na hodinách zemepisu. 1. vyd. Prešov : Metodicko-pedagogické centrum, 2005. 54 s.

ĎURIČ, L., BRATSKÁ, M. a kol. Pedagogická psychológia, Terminologický a výkladový slovník. Bratislava : SPN - Mladé letá, 1997. ISBN 80-08-02498-4.

GRIŠČÍKOVÁ, A. Didaktické hry s učebnou pomôckou lego. 1. vyd. Prešov : Metodicko-pedagogické centrum, 2007. ISBN 80-8045-425-6.

HAVERLÍKOVÁ, V. Stimulácia poznávania fyzikálnou hrou „Súboj na labilnej tácke“. In. Zborník príspevkov: Tvorivý učitel' fyziky III. Národný festival fyziky 2010. Bratislava : Vydala Slovenská fyzikálna spoločnoste, 2010, s. 141-147, 197 s. ISBN 978-80-96124-9-0.

HORVÁTHOVÁ, J., HAVERLÍKOVÁ, V. Využívanie metódy hry vo vyučovaní fyziky. In. Sbornik konference: Mezinárodni Masarykova konference pro doktorandy a mladé vědecké pracovníky. 1. vyd. Hradec Králové : MAGNANIMITAS, 2010, s. 153-158. ISBN 978-80-86703-41-1, ETTN 042-10-10003-11-4.

HORVÁTHOVÁ, J., HAVERLÍKOVÁ, V. Hra ako vyučovacia metóda - predstavy učitelov fyziky. In. Recenzovaný zborník príspevkov vedeckej konferencie s medzinárodnou účastou - Sapere Aude 2011. Hradec Králové : MAGNANIMITAS, 1. vyd. 2011, s. 485-490. ISBN 978-80-904877-2-7, ETTN 085-11-11006-03-8.

HRICOVÁ, I., JAKUBÍKOVÁ, J., TULENKOVÁ, M. Hry a kolektívne úlohy v prírodopise. 1. vyd. Prešov : Metodicko-pedagogické centrum v Prešove, 2003, 58 s. ISBN 80-8045-294-6-4.

CHRÁSKA, M. Metody pedagogckého výzkumu. 2. dotlač. Praha : Grada, 2010. ISBN 978-80-247-1369-4.

KÉVEŠOVÁ, J. Didaktické hry z matematiky. 2003. [cit. 22. 3. 2011]. Dostupné z: 〈http://media1.k-janka.mypage.cz/files/media1:4d32f11ca0e38.doc.upl/ DH\%20-\%20MATEMATIKA.doc $\rangle$

KÉVEŠOVÁ, J. Didaktické hry z prírodovedy. 2006. [cit. 22. 3. 2011]. Dostupné z: 〈http://media1.k-janka.mypage.cz/files/media1:4d46f15f4255c.doc.upl/ DH\%20-\%20PR\%C3\%8DRODOVEDA.doc)

KOLBASKÁ, V. Hra ako integračný prostriedok vo vyučovaní matematiky základných škôl. 1. vyd. Bratislava: Metodicko-pedagogické centrum v Bratislave, 2006, 
40 s. ISBN 80-8052-276-6. [cit 21. 8. 2010].

Dostupné tiež z: 〈http://www.mpc-edu.sk/library/files/kolbaska_hra_lp.pdf .

KRUPKA, P. Matematická didaktická hra a PowerPoint. 2007. [cit. 25. 8. 2010]. Dostupné z: 〈http://gynome.nmnm.cz/konference/files/2007/sbornik/krupka1.pdf〉

MARENČÁKOÁ, A., KARÁSZOVÁ, V. Tvorivá dielňa: Hry a hračky. In. Zborník príspevkov: zo seminára Šoltésove dni 6.-7. decembra 2006. Knižničné a edičné centrum FMFI UK. Bratislava, 2007, s. 75-80. ISBN 978-80-89186-17-4. 106 s. [cit. 25. 9. 2010] Dostupné tiež z: 〈http://www.skola.sk/podporovane-projekty/

fyzika-okolo-nas/zbornik/zbSolDni06.pdf $\rangle$

PETLÁK, E. V̌̌eobecná didaktika. Bratislava : 1997.

PIVEC, M., DZIABENKO, O., SCHINNERL, I. Aspects of Game-Based Learning. 2004. [cit. 21. 3. 2011].

Dostupné z: 〈http://eric.ed.gov/ERICWebPortal/recordDetail?accno=EJ710747〉

PRŮCHA, J., WALTEROVÁ, E., MAREŠ, J. Pedagogický slovník. Praha : Portál, 1998.

SABOL, J. a kol. Didaktické a zábavné hry v školskom klube. MPC Banská Bystrica. 2000-2004. [cit. 5. 2. 2010]. Dostupné z: 〈http://www.jozefsabol.sk/pedagogovia/ sabol/sabol_volny_cas/02_didakticke_a_zabavne_hry_v_skd.doc)

TEPLANOVÁ, K. Ako transformovat vzdelávanie : Stratégie a nástroje SCHOLA LUDUS na komplexné a tvorivé poznávanie a učenie. 1. vyd. Bratislava : Metodickopedagogické centrum, 2007, 120 s. ISBN 978-80-8052-287-2.

TRYBUS, J. Game-Based Learning: What it is, Why it Works, and Where it's Going. 2009. [cit. 20. 8. 2010]. Dostupné z: 〈http://www.newmedia.org/ game-basedlearning-what-it-is-why-it-works-andwhere-its-going.html $\rangle$.

ÚIPŠ: Štatistická ročenka, [cit. 6. 8. 2011]. Dostupné z: 〈http://www.uips.sk/prehlady-skol/statisticka-rocenka-suhrnne-tabulky〉

VANKỨS, P. Zbierka didaktických hier určených na integráciu do vyučovania matematiky na druhom stupni základnej školy. Bratislava : 2003, [cit. 31. 12. 2010]. Dostupné z: 〈http://www.ddm.fmph.uniba.sk/files/vankus/zbierka.pdf〉

WASTIAU, P., KEARNEY, C., BERGHE, W. Ako sa využívajú digitálne hry na školách? Záverečná správa. 2011. [cit. 6. 8. 2011]

Dostupné z: 〈http://www.rirs.iedu.sk/Dokumenty/Ako\%20sa\%20vyu\%C5\%BE\%C3 \%ADvaj\%C3\%BA\%20digit\%C3\%A1lne\%20hry\%20v\%20\%C5\%A1kol\%C3\%A1ch \%20Kompletn\%C3\%A9\%20v\%C3\%BDsledky\%20\%C5\%A1t\%C3\%BAdie.pdf $\rangle$

\section{POĎAKOVANIE}

Táto práca bola podporená Agentúrou na podporu výskumu a vývoja na základe zmluvy č. LPP-0395-09.

PaedDr. Jana Horváthová - E-mail: Jana.Horvathova@fmph.uniba.sk

PaedDr. Viera Haverlíková, PhD. - E-mail: vhaverlikova@fmph.uniba.sk

Univerzita Komenského v Bratislave, Fakulta matematiky, fyziky a informatiky

Katedra teoretickej fyziky a didaktiky fyziky

Mlynská dolina, 84248 Bratislava 4, Slovenská republika 